\title{
Project: Verbivore
}

\author{
It's a write off. \\ James Lovegrove \\ UK SECRET - CLEARANCE LEVEL \\ EYES ONLY \\ [NEWLY DECLASSIFIED] \\ Colonel \\ Chilton Mead Research Facility \\ nr High Leversham \\ Wilts \\ 17th March 1977
}

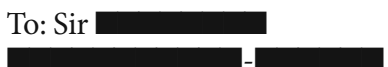

Ministry of Defence Main Building Whitehall

London SW1

\section{My Dear}

I hope this finds you well. Life at Chilton Mead continues in its usual way, one long round of meetings, meetings and more meetings, with the occasional top-to-toe budgetary review to liven things up. June can't come soon enough, as far as I'm concerned. I only get a fortnight off but I need the break. I'm very much looking forward to attending your Silver Jubilee bash at your place in . It's been so long since I last saw and of course young not to mention the delightful I hear her flute playing is coming along a treat and the music scholarship to Roedean was greatly deserved. Together, we shall all raise a bumper and toast Her Maj, God bless her. Fine woman, as I'm sure you know. Long may she reign.

Anyway, down to business. You asked me to furnish you with a report on the progress of Project: Verbivore. Sad to relate, things haven't gone so well. That isn't to say that the project hasn't been a success. It's simply that the results have proved unfeasible in practical terms.

Let me explain. As part of our continuing efforts at Chilton Mead to develop new and subtle methods of prosecuting war against our enemies, we have been looking into ways of undermining their intelligence-gathering and record-keeping capabilities. Destroy the informational infrastructure, destroy the foe - that's our somewhat unwieldy motto.

Now, the science johnnies here are, as you know, some of the brightest and weirdest boffins on the planet, and they don't come much brighter or weirder than Professor Can't stand the fellow, personally. One of those drawling longhairs who seems to

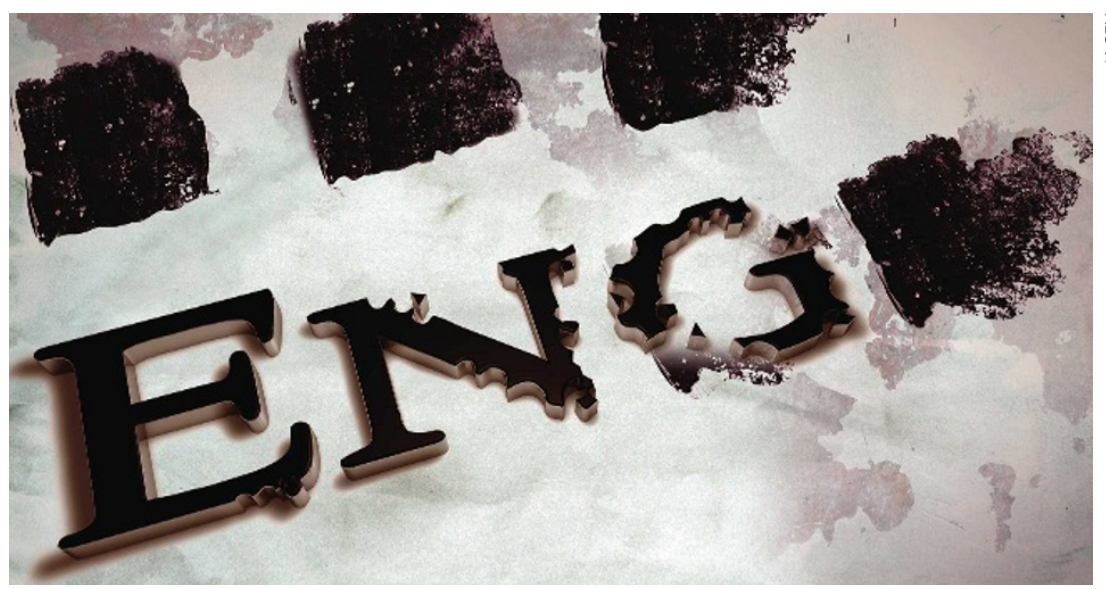

resent having to work for the military to earn a crust and who has no respect for my authority - or anyone else's for that matter. The number of times I have had to reprimand him for his slovenly manner and his refusal to address me by my rank. And all I get in reply is 'Hey, cool it, man' or some other such ghastly, slack-jawed modernism.

However, his Verbivore concept, which you were understandably very taken with when I briefed you on it last year, seemed to be the perfect solution to the matter at hand: a bacillus that eats words.

Don't ask me to explain how it works. I honestly have no idea. Professor spoke in terms of engineering microbes with a taste for one particular foodstuff, much as certain lichens will grow only on certain trees and certain moulds only on certain cheeses. Most of this stuff is right over my , more akin to magic than science. I just accept it now, after 11 years in charge at a place where white-coated whizz-kids can make graffiti sing and fleas dance the hula.

The Verbivore bacillus consumes the written word with locust-like voraciousness, leaving nothing but a black stain behind. 'Verbivore spoor,' Professor called it, with one of those sloppy, lopsided grins of his. (I refused to grace him with a laugh but I thought it quite a witty turn of phrase nonetheless.) Once released on a target piece of text, the bacillus grows and multiplies at speed, munching through words at the rate of two per hour on average, meaning it can eradicate the best part of a paragraph in a day.

The only trouble is - here's the catch - Professor bred it too specialized. Try as he might, he couldn't get the Verbivore to vary its diet. We tested it both here and in the field. Our best men in Moscow and Peking, agents and , applied it to certain documents that passed under their noses.
They also applied it to microdot film and to blueprints. Nothing doing. Verbivore turned its nose up and starved to death.

Verbivore, you see, eats only English. It cannot stomach Cyrillic or Chinese script. It is too patriotic a bacillus, too partial to our vocabulary. It won't touch any other language, not even ones that use the same alphabet. French? Show it a DGSE memorandum and it loses its appetite in a flash. German? Instant indigestion. Italian? Not a hope.

As you can imagine, it therefore of no appreciable use to us. Indeed, all said and done Verbivore is pretty an own goal. It will erase our own documents, and those of American and Canadian allies, without a moment's hesitation, leaving them a patchwork of black blanks. As such it may be considered a and even a hazard to security. Consequently I have had no but to order the project and see to it that Prof destroys all existing samples of the As you can imagine he was rather miffed about this and threatened to his own back on $\square$. How he'll manage that is hard say. I'd like to him try!

In any case, I'm sorry, that this is how things have out. I know you had high for the But you can see, surely, the risks of something like loose. We would render our own to more or less ! Talk about Still, live and eh? Back to the

Yours

James Lovegrove is the author of more than 20 books including Days, Untied Kingdom and Provender Gleed, and writes regular book reviews for the Financial Times. 